\title{
Limitless Deficit Financing for Economic Prosperity: Where They Got Keynes's Deficit Spending Wrong?
}

\author{
Sajid Amin Javed \\ Research Fellow, Sustainable Development Policy Institute (SDPI) \\ Islamabad, Pakistan
}

\begin{abstract}
The recent wave of recommendations of unlimited credit creation to finance government expenditures to achieve economic growth and prosperity seems to be grounded in misunderstanding Keynes's countercyclical fiscal policy. Keynes's deficit spending denotes the stimulus geared towards increasing private investment as opposed to big government spending boosting consumption. Taking Japan as a case study, I showcase that deficit financing meeting Keynesian preconditions, including a sound monetary system, well-developed financial markets, and lower/zero interest rate, may not lead to raising growth and lowering public debts as the proponents predict. I maintain that unlimited credit expansion to the public sector in consumption-based economies, which is the general case for developing countries, is most likely to generate inflation while leaving the economy's productivity unchanged.
\end{abstract}

Keywords: Keynes, Keynesian Policy, Deficit Spending, Credit Creation, Interest rate, Fiscal Policy.

JEL Classification: E12, E51, E62, H63, H81

KAUJIE Classification: G3, R72, R73, R81 


\section{Introduction}

The primary job of a macroeconomist is to look into the

important problems of the day [and try to answer:] (i) How are we to understand what is happening right now? (ii) What can be done about it? What is the best policy to follow? (iii) Do recent events force us to modify what, today, is widely accepted economic theory? If so, what is wrong and how might we go about arriving at a more satisfying theory? (Leijonhufvud, 2009, p. 741)

This is a dynamic process that macroeconomists continue to go through.

Sometimes, however, rooted in ideological alignments, macroeconomists may frame the "present day problems" in decades older frameworks and theories. Keynesians would try to find the solution from General Theory of Employment, Interest and Money; classical economists would try to explain present day unemployment framed in Say's law and monetarists would go back to the Basic Quantity Theory of Money to explain monetary problems of the economy.

Trying to draw policy lessons by framing present day issues to old frameworks trying to answer questions within a particular context of those days may lead to false or inefficient policy prescriptions. Barack Obama's stance that "the theories of John Maynard Keynes form the foundation for its fiscal policies" with reference to his policy of "spending big to pull out of a recession" (Tully, 2010, para 1) presents one such example. Those who understand Keynes's version of deficit spending believed that the

[Obama] administration got Keynes only half right. [According to Allen Meltzer], it's [Obama administration] neglecting a key part of Keynes' plan: You can't run up a debt without a way to cover it.

[Meltzer continued that]; The type of stimulus he [Keynes] advocated was very specific. He said it should be geared towards increasing private investment. He viewed private investment, as opposed to big government spending, as the source of durable job creation. He also said that the deficits should be self-liquidating, so that the increased economic activity caused by the stimulus inevitably generated a combination of extra tax revenues and lower unemployment payments. With higher revenues and lower outlays, the deficit would disappear. The
Obama administration's main objective, in the name of Keynes, is boosting consumption. That sounds very different from the focus on investment that you say Keynes advocated. Keynes didn't favor at any time that I know spending to increase consumption. He didn't want that, and in fact he believed that was taken care of by the marketplace. (Tully, 2010, paras 2, 3, \& 11-13)

The debate on deficit financing has always earned serious concerns because of persistent budget deficits and financing thereof across the world, particularly in developing countries (for details, see: Feltenstein \& Iwata, 2002). The debates mainly hoover around Ricardian and Keynesian versions of deficit financing wherein the former is referred to be the traditional viewpoint. A recent addition is Heterodox Macroeconomics School's Modern Monetary Theory (MMT) version of deficit financing which is closer to the Keynesian version. Both seem advocating unlimited sovereign indebtedness in the name of Keynes's countercyclical fiscal policy.

MMT essentially maintains that sovereign governments have a monopoly over issuing currency and that governments can issue as much money as they want to pay for bridges, education, defense, or whatever. MMT further maintains that any inflation resulting from printing money can be controlled by hiking taxes ${ }^{(1)}$. In this way, government takes away the excess money supply it created in the first place. Virtually, MMT, to advance deficit financing, limits tax policy only to taking excess money supply away from the market ignoring its distributive, productivity, and other impacts.

Whereas traditional theory opines that deficit financing has serious socioeconomic implications including, but not limited to, increased inflation (if the deficit is financed through printing money) and higher interest rates (if the deficit is financed through bank borrowing without printing money which also crowds out private investment). Modern Keynesians, following Keynes, deny any such costs outlined in the 'conventional viewpoint'. Most fundamentally,

(1) It is also important to note here that the period for which high inflation impact will prevail before it is taken away depends upon how taxes are imposed (fiscal policy announcements) and collected (annually, quarterly, etc.). 
they take the position that deficit financing is the most effective tool to increase national income, control deficits, and lower debt to GDP ratios, given some preconditions.

In this regard, recent debate goes to the extreme viewpoint of recommending unlimited credit creation to finance budget deficits. Savings, in this debate, are totally discarded of any role to run the economy, including investment. This extreme viewpoint results from framing modern day persistent deficits to the recession of 1930's and confusing Keynes's deficit spending with modern day deficit financing.

In this article, I argue that the two are radically different from each other and that clearing the confusion leaves the conventional viewpoint more relevant to modern day budget deficit issues. And that modern-day deficits do not match with investmentdeficient recessions which Keynes actually mentions while recommending deficit spending. Keynes's advice to increase spending in recessions, not to be confused with structural deficit, was meant to fill the deficient investment.

Also, I maintain that modern-day conclusions that 'savings are not required for investment' overly rely on Keynes's view point that 'investment is not an exclusive function of the interest rate' to suggest that 'credit creation' is the absolute cure to meet investments and finance deficits as argued by Pettifor in her lead paper (2019, p. 67). Finally, I contend that deficit financing has its limits and that recommenddations for infinite credit creation to finance deficits are rooted in misinterpreting deficit spending of Keynes.

\section{Deficit Financing, Instruments and Some Big "Ifs"}

The final impact of deficit financing depends on the source of financing the government may opt which include: (i) borrowing from the central bank of the country (without printing new money); (ii) borrowing in the form of printing new notes; (iii) commercial banks; and (iv) borrowing from non-financial sectors, i.e., saving centers and insurance companies (governments may also finance deficit through external borrowing increasing the external debt). The final impact depends on the source used to finance the deficit.
The most obvious ways of financing the deficit include: taxes, borrowing, and monetization which are also called as inflation tax. Among the aforementioned, the most popular mode of financing the deficit is borrowing. Borrowing in this domain is usually done by issuing government bonds. This act of issuing government bonds decreases the real value of money and hence future uncertainty for the economic agents.

There are various channels/mechanism through which growing public debt or growing deficit financing has an effect on the economy. The increased sale of government bonds will increase the market interest rate. This rising interest rate has the implication of fiscal deficit in the future. Being correlated with the investment and public expenditure component, the growing deficit financing may have serious effects on the perspective economic performance.

\subsection{Bank Borrowing Without Money Creation}

Financing budget deficit via loans from banks have negative inflationary effects. In this way of financing budget deficits, there is a possibility of redistribution of money already in circulation which may increase the stock of money in the economy. The central bank is involved to rediscount operations of commercial papers of the commercial banks. The banks' liquidities are increased via granting refinancing credits which cause credit-based inflation.

As it is well-known that government debt is retuned by taxes in the future. Such anticipated future taxes discourage savings while encouraging present consumption and worsening the situation in a regime of trade and financial repression. It is suggested, therefore, to avoid financing deficit via domestic open market borrowing. If the situation is such that access to the foreign capital market is restricted for the private sector, then domestic borrowing will crowd out domestic investment. It is important to note that crowding out is not necessarily because of higher interest rate; instead it is because of reducing the amount of rationed credit available to private investors.

To leave this argument ineffective, the extreme view point of deficit financing contends that in a modern economy savings are an outcome of 
investment and not the driver of investment. The proponents take help from Keynes's infamous stance that savers and investors are two different groups. However, this argument has weak grounds when put into the context of what Keynes means by deficit spending and how modern-day deficit financing is channelized towards consumption rather than promoting private investment as was the idea of Keynes's deficit spending.

\subsection{Bank Borrowing Based on Money Creation ${ }^{(2)}$}

Financing requirement is also meet via creation of new money by the central bank of the country. This is the most widely used source of deficit financing. In this regard, the treasury bills issued by the government are bought by the central bank for cash created by printing new money. This has the adverse effects of an increase in the money supply which are inflationary in nature and are also accompanied by some other social evils. This is particularly true if new money is used to finance consumption, as is the common case in developing countries.

At first, the increase in inflation has a direct impact of lowering the real value of money and resultantly the reduction in purchasing power of the poor. Hence, inflation created by issuing new money by the central bank redistributes the purchasing power from the poor to the rich. Higher inflation, through increased cost of production, unevenly affects the export industry leaving it uncompetitive. Contrary to the argument of deficit financing reducing deficits, this may further balloon the deficits.

\subsection{Public Borrowing}

Collecting resources for financing the budget deficit via public borrowing is a temporary measure. The loan from the public is costly as well because the government has to pay a certain amount of interest. Resultantly, this type of raising revenue has the undesired effects of accumulation of public debt along with an increase in interest payments. Therefore, meeting the financing requirement via public borrowing doesn't increase the money supply which is in circulation and, hence, has no inflationary effects. Meeting the financing requirement via public

(2) If this is maintained through asking commercial banks to keep higher reserves with the central bank, it is similar to taxing financial intermediaries. borrowing is regarded as financing the budget deficit in contemporary society and so is considered a better mode of financing.

It is worth noting also that the "economic activity increasing' impact of deficit financing warrants a change in the 'rate of use of money' as an initial effect. This is only possible through the instrument of 'expansion of money' which is inflationary by definition (Warburton, 1945, p. 74). Most importantly, however, the said 'economic activity' to be financed by monetary expansion based fiscal spending may have already taken place. Deficit financing through any other method does not lead to an increase in economic activity

Also, the argument that a government's deficit spending is other's balance heavily grounds on the assumption that only government can have deficit spending. Deficit spending is not limited to governments only. In addition to the treasury, an economy comprises of governments, profit-making business enterprises, nonprofit enterprises, groups and voluntary societies of great variety and type, and individuals. Any of these, other than the government can opt for deficit spending "though the monetary powers of the federal government give it an ability to carry deficit spending to greater extremes than can be done by other parts of the economy" (Warburton, 1945, p. 79).

Proponents of unrestricted deficit spending,

need to consider, therefore, whether deficit spending by government has an effect on business stability and the rate of economic activity significantly different in character from deficit spending by other segments of the economy, and by how much total deficit spending in the economy may be greater or less than that by the federal government.

... [D]eficit spending by government and business met by borrowing from nonbanking sources, together with business financing by equity capital, represent money drawn from the preexisting income stream. Such financing, like taxation, transfers the use of money for expenditure on final products, on one of its 'rounds of expenditures", from individuals to business or to government, and cannot alter the size of the income stream except as the process of transfer may retard or activate the rate of use of money. (Warburton, 1945, p. 79) 
The forgoing discussion corroborates that only deficit spending based on money creation has a positive impact on the income stream, but an opposite impact of shrinkage in income size is created when the debt of the banking system reduces. Most importantly, deficit financing per se has no income stream increasing impact. The impact is contingent on the change in the rate of use of money and many other institutional factors. One can conclude

(a) that deficit spending per se has a negligible influence upon the rate of economic activity or the size of the income stream; (b) that monetary expansion associated with an increase in business, governmental, or individual borrowing from the banking system has a direct proportional effect on the size of the income stream subject to the influence of accompanying changes in the rate of use of money, if such $\operatorname{occur}^{(3)}$. (Warburton, 1945, p. 81)

This leads to the conclusion that deficit financing may have a positive impact in one region, at a particular time, and may not have that impact in some other regions or some other time depending on the local context. This is contrary to the men of multipliers' suggestion of 'unlimited sovereign indebtedness' being panacea for everyone, everywhere, and every time. The literature clearly suggests "that $a$ priori reasoning does not provide grounds for believing that deficit-financing will significantly retard or accelerate the rate of use of money" (Warburton, 1945, p. 81).

\section{Unbundling Deficit Spending of Keynes}

The literature immediately after the 1930's Great Recession clearly suggests that

Maintenance of a high national income, and with it a high level of employment, is not dependent upon government spending - either pump-priming, compensatory, or permanent - nor upon continuance of a government deficit nor a compensatory deficit. (Warburton, 1945, p. 84)

And that

The rise and vogue of the theory of deficit spending should be attributed to the inadequacy of monetary policy since the middle 1920 s, that inadequacy being expressed in an absence of normal growth in the volume of money in 1929, a violent monetary

(3) This "if such occurs" serves as a limit on the endless gains of Keynesians' deficit spending. contraction during 1930-33, and an irregular rate of growth since 1934 largely associated with government activities (Warburton, 1945, p. 84)

The recent wave of Keynesians, confusing deficit spending of Keynes with modern-day deficit financing, views deficit financing as an unrestricted tool to uplift the economies from recessions, to achieve economic growth, to activate idle resources, to attain higher income and employment level, and to enhance capital formation. The argument that credit creation or panacea to all investments and one needs no savings implies no role for the taxation system.

The proponents argue that deficit financing leads to an increase in developmental expenditure on building infrastructure in respective countries (see, e.g., Okoro, 2013; Ojong, Hycent, \& Effiong, 2013). Thus, it expands governmental activities. This can increase the national income through the multiplier effect which, in turn, lowers the debt to GDP ratios. It is, however, important to note that this impact will be frail if the deficit financing is used for non-developmental expenditures like debt servicing and debt retirement which is the case in developing countries.

Most importantly, present day deficit financing is used to inflate consumption and negligibly focuses on increasing the private investment, what Keynes meant by deficit spending actually. This fundamental difference leaves economies with ever mounting debt accumulations, structural deficits, and lower productivity levels prevailing.

The argument that deficit financing leaves certain multiplier effects on the economy leading to expansion in employment and income level (Okoye \& Akenbor, 2010) may hang at its own if the government finances consumption not the investment. This also has implications for the 'unused productive capacity' argument forwarded by supporters of limitless deficit financing.

The capacity may remain unused when deficit expenditure does not bring about private investment in the economy. 'Unused capacity' of the manufacturing sector and industry, going beyond mere availability of credit, is rooted in structural reasons including, but not limited to, lower labor productivity, skill deficit, lower capacity to participate in modern technology, and methods of production. 
Furthermore, the argument that deficit financing is the most effective tool to reduce public debt as a ratio of national income warrants serious reconsideration. First, the impact depends upon the nature of government expenditures. Deficit financing not channelized to promote private investment, as Keynes wanted it to be, may give a flip to the economy in the short-run but fail to bring any sustained increase in national income. Second, it may further accumulate debts through increasing the deficit in the medium to long run.

Higher interest rates, resulting from increased demand for credit over its supply, may lower economic activity through higher costs of investment and production. At the same time, it increases the cost of servicing the local debt. Third, the inflation, when deficits are financed by printing new money, increases the cost of production. Fourth, and most importantly, higher inflation may appreciate the real exchange rate making the export sector uncompetitive. This further shrinks the economic activity. The effect of deficit financing is also sensitive to the exchange rate regime, in addition to the instrument used to finance the deficit (for details, see Descalzi \& Neder, 2017).

A higher demand for credit over its supply causes the interest rate to rise, citrus paribus. This resultantly crowds out private expenditure in the interest sensitive sector of the economy which might retard capital formation and overall economic growth in a close economy. In contrast, deficit spending would increase the domestic interest rate, assuming an open economy characterized by a floating exchange rate and perfect capital mobility. As a result, the inflow of financial capital will appreciate the exchange rate and, hence, a current account deficit in the balance of payments. Overall, deficit spending is positively related with the interest rate, price rise, and trade deficit.

\subsection{The Zero Interest Rate Deficit Financing Logic}

The proponents of unlimited deficit financing justify the position in the name of low or zero interest rate deficit financing. The justification for zero or lower interest rate is derived from the observations that interest rates fall in recessions. This is where they go wrong associating deficits with recessions exclusively. Primary deficits in a boom grow along with growing public debt. The USA presents a best example in this regard. The idea of zero-interest financing has been discussed in detail immediately after Keynes.

The idea of interest free financing is as old as the idea of deficit financing itself. As noted in Poindexter (1944, p. 438), David McCord Wright introduced multiple options for interest free bank credit in his book The Creation of Purchasing Power. The idea of financing public works and reducing public debts through interest free bank credit has been seriously challenged in very early days of its development.

In the words of Poindexter (1944),

In a democracy, if it were possible for the government to finance its undertakings, sound and unsound alike, without incurring the traditional economic and political penalties, it is difficult to believe that such a good thing would not be overdone, with disastrous consequences to the community. Furthermore, even with the wisest and most responsible of men in control of the government's finances, the popular reaction to such a method of financing would probably be such as to make it politically impossible for the authorities to effect the appropriate changes in the volume of government spending at crucial times, or to impose the indicated tax deterrents in the face of an inflationary menace. ...

The conclusion seems inescapable that quasi-costless deficit financing and adequate or acceptable methods of preventing inflation are incompatible with each other; or, if the two can be reconciled, that the necessary conditions would be a drastic contraction in the scale of the existing banking structure, an arbitrary shifting of financial burdens to the public, plus the adoption of highly mischiefvous control devices. (p. 458-459)

It should be noted here that in this paper, the issue of zero interest rate is not discussed in the context of the Islamic economic system. Hence, the conclusion that zero interest rate deficit financing does not work in no way means not having an interest free economic system. It simply suggests that in present economic structures, unlimited deficit financing may not work even if all Keynesian preconditions are met. 


\subsection{What Keynes Actually Said About "Deficit Spending"}

Contrary to common belief that Keynes was a 'deficit lover', Keynes believed that booms and busts are a routine part of the business cycle. Again, contrary to the belief that Keynes has only one policy prescription of deficit spending by the federal government for income creation, economic stabilization, and full employment, he wanted socialization of investment. This was one of the three main ideas of Keynes, 'parting with liquidity', 'euthanizing the rentiers', and 'socializing investment'. For Keynes, to socialize investments,

[i]t is not the ownership of the instruments of production which it is important for the State to assume. If the State is able to determine the aggregate amount of resources devoted to augmenting the instruments and the basic rate of reward to those who own them, it will have accomplished all that is necessary. (Keynes, 1978, vol. 7, p. 378)

The idea of unlimited credit creation and deficit spending without any limits is not consistent with Keynes. And this has brought economic destabilization whenever and wherever practiced, including the USA (Brown-Collier \& Collier, 1995, p. 341).

As noted in Brown-Collier and Collier 1995, Keynes was clearly against the idea of "collecting in taxes less than the current non-capital expenditure of the state as a means of stimulating consumption" (Keynes, 1978, vol. 27, p. 406). Also contrary to the present-day concept of deficit financing of consumption and MMT's idea of unlimited credit creation to inflate aggregate demand, Keynes supported countercyclical fiscal policy with increasing spending in deficits - in the form of investments - as, for him, the deficits were an outcome of shortage of revenue resulting from lower economic activity.

But the latter part of the argument, which seems to suggest that the tendency of the proposals is to unstabilise the national budget, is surely topsyturvy. It would be a failure to adopt a remedy for severe cyclical unemployment which might have that effect. There appears to be no glimmer of a recognition that measures to stabilise the national income are ipso facto measures to stabilise the national budget. The additional charges falling on the budget in years of bad employment as a result of the Committee's proposals are, in fact, almost negligible; whilst the effect on the revenue of maintaining the national income should be obvious. ... It would be a failure to take such measures which would inevitably unstabilise the budget and weaken confidence. Is it supposed that slumps increase the national wealth? (Keynes, 1978, vol. 27, p. 366)

Furthermore, a look into Keynes's proposals for government budgets clearly suggests that he discouraged government to deficit finance current expenditures. Keynes was equivocally in favor of "borrowed funds that are repaid over the service life of the project" and raising revenue through taxation "budgeted so as to meet these payments". Most importantly, the present debate on deficit spending seems to ignore Keynes's clear differentiation between ordinary and capital budget of the government wherein he strongly opposes any deficit in the "current or ordinary budget" (Brown-Collier \& Collier, 1995, p. 350; see also Bassetto \& Sargent, 2006, for an insightful discussion on the politics and efficiency of separating the two).

Present day deficit financing, particularly in developing countries, is devoid of this careful consideration and is most channeled to finance ordinary budget. Also, present day deficit financing is responding to changes in income and consumption, rather than investment. This is in exact contradiction to the economic policy proposed by Keynes wherein "[b]orrowing to finance public investment was justified on the grounds that the capital acquired provides a real return over time" (Brown-Collier \& Collier, 1995, p. 354).

\section{Deficit Spending, Unlimited Credit Creation and Japan}

The recent wave of Keynesians, based on Keynes's infamous demand creates its own supply, believe that revenues are no problem and that expenditures hold the key in economic activity. This is partially true. Expenditures are investment in future revenues. However, this wave of Keynesians gets the other half wrong. They go to the extent that to meet its expenditures, government does not need to rely on savings as it can have unlimited sovereign indebtedness. Though different in mechanism, MMT reaches a similar conclusion (Pettifor, 2019, p. 67). Its defense of unlimited deficit financing is based on the argument that it is credit creation which finances the 
deficits and no new money is printed. Hence, without fearing inflationary pressure, government can finance as much as it likes. Apparently, it solves the inflation problem associated with conventional deficit financing. In other words, "deficits don't matter" (Pettifor, 2019, p. 67).

This group of Keynesians maintains that the only limit to financing expenditures a country/ government can face is the lack of a "well-developed monetary system" and that savings are no more a limit. Reliance on savings actually denotes the absence of a sound monetary system (Pettifor, 2019, pp. 67-78). This school of thought also maintains that the presence of a sound monetary system deletes reliance on all sources of finances, including local domestic and international capital markets, multinational organizations like the IMF and the World Bank, and other bilateral arrangements.
The logic is simple. A government having a monopoly on issuing currency and a well-developed monetary system needs no other sources. In line with Keynes's 'realm of dignity' of nation, it can create credit as much as required to finance the deficits and investment, virtually with no constraints. The evidence from the literature of credit creation (money creation includes credit creation plus printing/manufacturing new money) and creating sovereign debts however, shows that the process has injected instabilities in the economic system.

One needs not to go far back to see these kinds of instabilities. The global financial crisis of 2008-2009 is just a matter of few years back. The banks created too much in credit and too quickly that it destabilized the economic systems.

\section{Figure (1) The Money Supply and Credit Creation by Banks: UK}

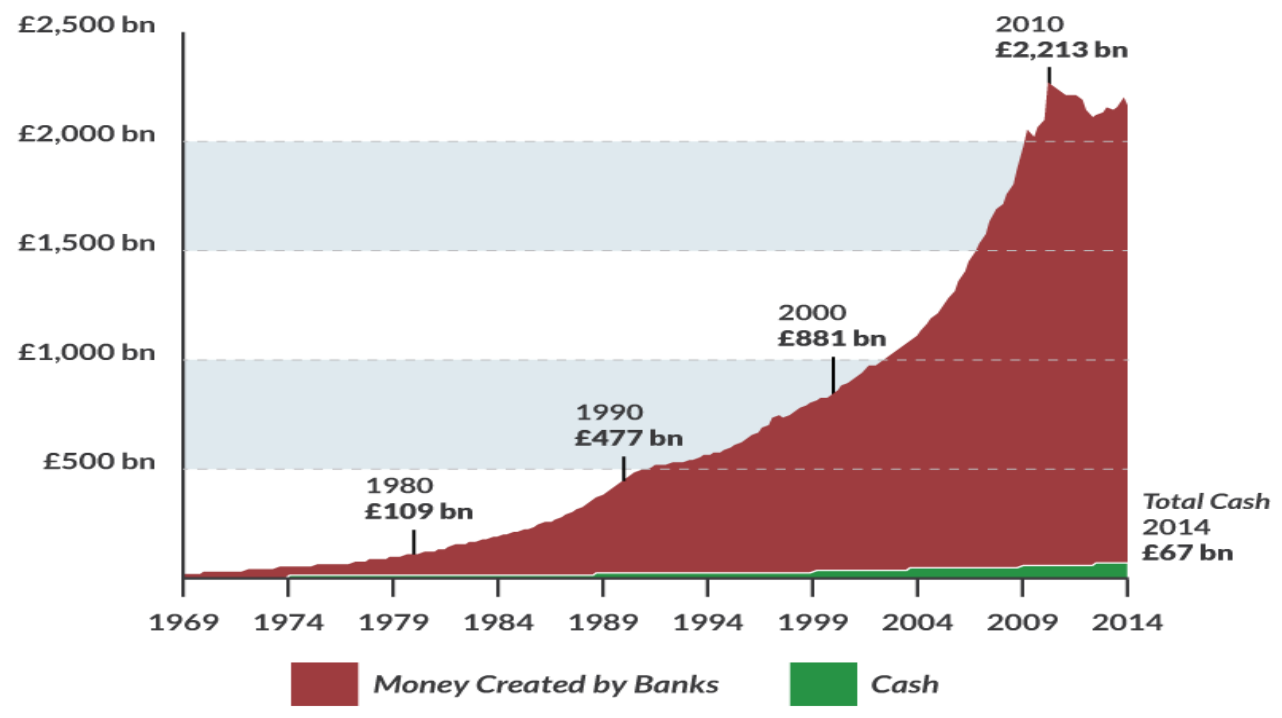

Source: https://positivemoney.org/issues/recessions-crisis/

Figure 1 clearly suggests that credit creation in the UK witnessed a staggering growth of $1276 \%$ over a period of 1980 (credit GBP 109 billion) to 2007/2008 (Credit GBP1500 billion). The ratio of cash to credit in the UK economy documented a dip. In 2014, the ratio of cash to credit stood at 0.03 . Most importantly, about $31 \%$ of this growth in credit was consumed in residential real estate property. This resulted in a price boom in the sector surpassing the wage growth. Only $8 \%$ of the credit went into businesses (Positive Money, n.d.). In the words of Adair Turner, the former chairman of the UK's Financial Services Authority, "the financial crisis of 2007 to 2008 occurred because we failed to constrain the financial system's creation of private credit and money" (Turner, 2013, p. 12). 
Japan $^{(4)}$ offers a good lesson contrary to the predicttions of the men of deficit spending. Since the stock market crash of 1990, Japan has had virtually zero interest rate and has heavily financed its infrastructure and other public sector spending based on credit creation (Figure 2).

Technically, it corresponds to a real-world application of zero interest rate financing backed by a sound monetary system and a well-developed financial and capital market. The outcome, however, was different than what present day Keynesians teach us to be. Despite "Enormous amounts of money were spent on 'bridges to nowhere' and other, hopefully better motivated, projects until Japan's national debt grew to a size that discouraged any continuation of the policy" (Leijonhufvud 2009, p. 745).

If the modern definition of deficit spending is any guide, Japan's debt, as a share of GDP, should have declined. However, the data shows that it was the other way around. Japan's total public debt ballooned to roughly $255 \%$ of GDP in 2018 from $60 \%$ in 1990 and $192 \%$ in 2008 (Figure 3). Japan was not able to achieve the growth as credit theory of banking predicts where each unit of credit created transforms to the expansion of goods and services, and hence increases national income (see, Koo, 2003, for an account of structural reasons in this regard).

With particular reference to this study, the experience of Japan has a very important lesson that

$[\mathrm{O}]$ nce the credit system had crashed a central bank policy of low interest rates could not counteract this intertemporal effective demand failure. Year after year after year, the Bank of Japan kept the bank base rate as close to zero as makes no difference and even then the economy was under steady deflationary pressure and healthy growth did not resume. (Leijonhufvud, 2009, p. 746)

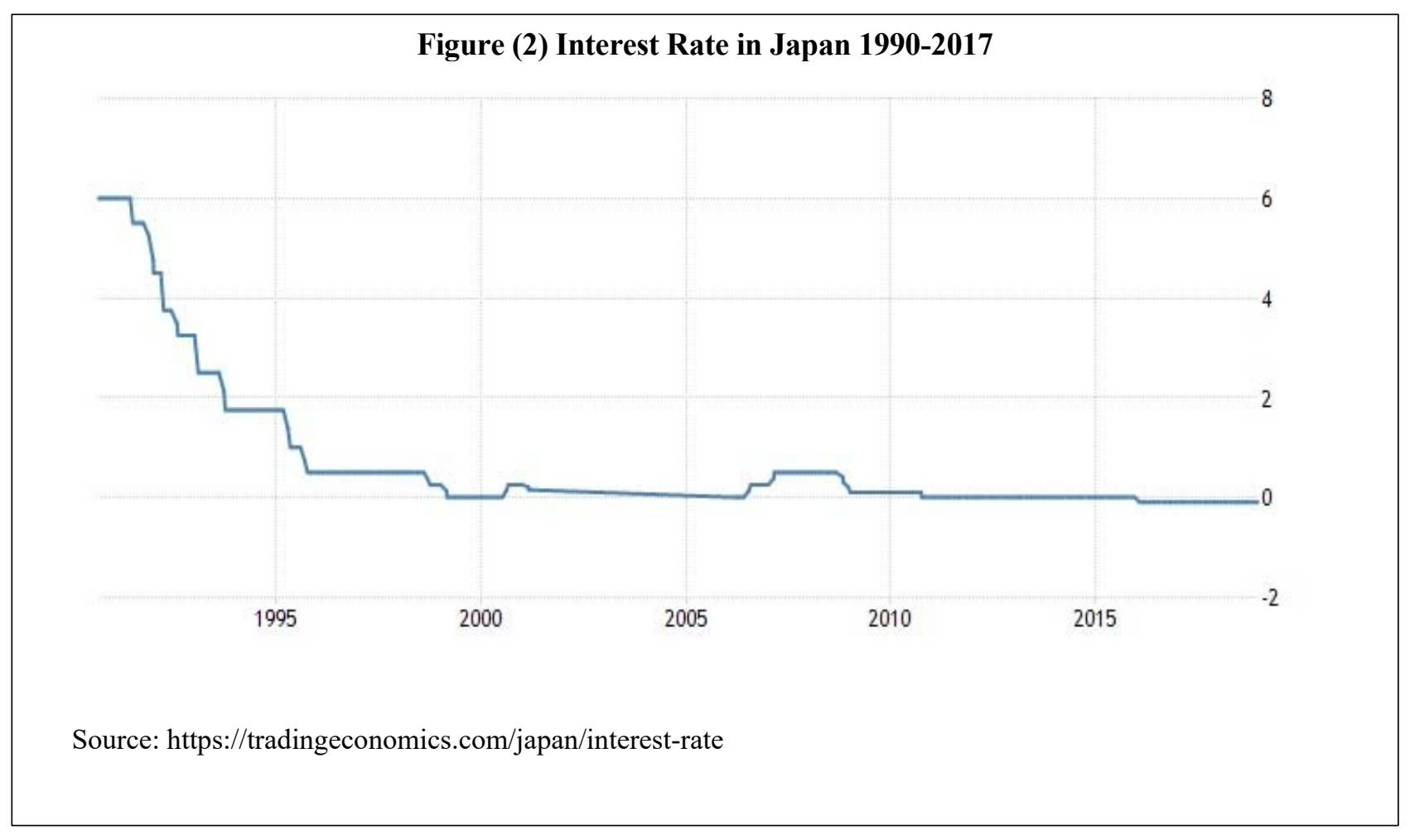

(4) The UK and Japan as case studies were selected purposefully as these economies meet the Keynesian pre-conditions for the so-called "unlimited deficit financing". 
Figure (3) General Government Debt in Japan (1990-2017)

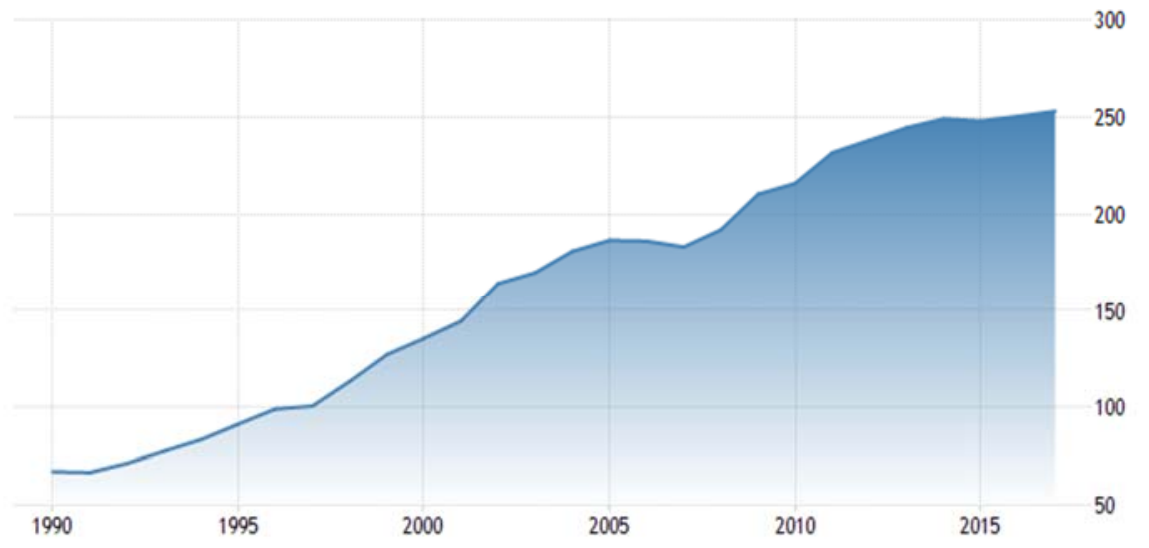

Source: https://tradingeconomics.com/japan/government-debt-to-gdp

\section{Summary and Conclusion}

Without ignoring the role of credit creation in modern day economies and recommending, in no way, that deficit financing should not be practiced, I make the following key observations:

(a) The present-day deficit financing is different from the deficit spending of Keynes.

(b) Unlimited credit creation is not panacea to every problem.

(c) I show that credit creation, practiced under all pre-requisites of Keynesian theory, has failed in Japan. Not only that the income growth was slower, but debt as a ratio to GDP in 2017 stands roughly four times higher compared to 1990 and a further increase is expected.

(d) It is maintained that zero interest rate deficit financing, which traces back to the 1940's, is not a sufficient condition for successful deficit financing and Japan presents the case. This has implications for 'unlimited sovereign indebtedness' as a magic bullet for economic growth and economic stability.

(e) I argue that present day crises are different from the 'investment shortage led recession' of the 1930 's and that framing present-day problems to decades old framework has led to false or inefficient policy prescriptions.

(f) The argument of 'unused capacity' must be contextualized for the reasons behind it. In developing countries, the unused capacity may not be an outcome of credit constraints rather it is rooted in the lower productivity of the factors of production. Credit creation would not be able to solve the issue.

(g) Also, credit expansion in consumption-based economies, which is the case for most of the developing countries, may fail to bring any productivity gains as it does not bring modern technology across the economy. Any credit expansion leaving the productive capacity of the economy unchanged makes inflationary effects of credit creation much more likely.

(h) Developing countries plagued with inefficient monetary systems, facing fiscal dominance, and under-developed financial markets, may suffer negatively if credit creation goes beyond an optimal level (Turkey's recent meltdown may present a case study). Particularly, structural deficit financing, a modern-day practice in developing countries, is anti-developmental in the long run because developing countries suffer from a shortage of capital equipment and other complementary resources, lack of technical knowledge and entrepreneurship, lack of communications, and market imperfections. I conclude that no-one shoe fits to all ${ }^{(5)}$.

(5) John Power, (1977), as cited in Remolona, (2002, p. 5), for example, contends that wages in the modern sector are determined by institutional factors leading to Marxian, rather than Keynesian, unemployment 


\section{References}

Bassetto, M., \& Sargent, T.J. (2006). Politics and Efficiency of Separating Capital and Ordinary Government Budgets. The Quarterly Journal of Economics, 121(4), 1167-1210.

Brown-Collier, E.K., \& Collier B.E. (1995). What Keynes really said about deficit spending. Journal of post Keynesian economics, 17(3), 341-355.

Descalzi, R., \& Neder, Á.E. (2017). Financing Fiscal Deficits: Intertemporal approach under different exchange rate regimes (Working Paper). Retrieved from: https://www.bcu.gub.uy/Comunicaciones/Jorna das\%20de\%20Economa/NEDER_ANGEL\%20ENRI QUE_2017_4850.pdf

Feltenstein, A., \& Iwata, S. (2002). Why is it so hard to finance budget deficits? Problems of a developing country. Journal of Asian Economics, 13(4), 531-544.

Keynes, J.M. (1936). The General Theory of Employment, Interest, and Money. London, UK: Macmillan and Co.

Keynes, J.M. (1978). The Collected Writings of John Maynard Keynes (D. E. Moggridge \& E. S. Johnson, Eds.). London, UK: Cambridge University Press for the Royal Economic Society.

Koo, R.C. (2003). Balance sheet recession: Japan's struggle with uncharted economics and its global implications. Singapore: Wiley.

Leijonhufvud, A. (2009). Out of the corridor: Keynes and the crisis. Cambridge journal of economics, 33(4), 741-757.

Ojong, C.M., Hycent, O.O., \& Effiong, C. (2013). Effect of Budget Deficit Financing on The Development of The Nigerian Economy: 1980-2008. European Journal of Business and Management, 5(3), 61-84.

Okoro, A.S. (2013). Government Spending and Economic Growth in Nigeria (1980-2011). Global Journal of Management and Business Research Economics and Commerce, 13(5), 21-30.
Okoye, E.I., \& Akenbor, C.O. (2010). An Empirical Investigation of the Impact of Deficit Financing on Socio-Economic Activities in Nigeria (from 19972007). Nnamdi Azikiwe University Journal of the Management Sciences, 10(1), 95-106.

Pettifor, A. (2019). 'Deficit Financing' or 'DeficitReduction Financing?' Debates in Contemporary Economics: Origins, Confusions and Clarity. Journal of King Abdulaziz University: Islamic Economics, 32(1), 67-78.

Poindexter, J.C. (1944). Fallacies of interest-free deficit financing. The Quarterly Journal of Economics, 58(3), 438-459.

Positive Money. (n.d.). Financial Crisis \& Recessions. Retrieved from: https://positivemoney.org/issues/ recessions-crisis/

Remolona E.H. (2002). Financing the Budget Deficit in the Philippines (Philippine Institute for Development Studies Working Paper No. 85-02). Retrieved from: https://dirp4.pids.gov.ph/ris/wp/pidswp8502.pdf

Tully, S. (2010, February 5). How Obama got Keynes wrong. Retrieved from: http://archive.fortune.com/ 2010/02/04/news/economy/meltzer_keynes.fortune/ index.htm

Turner, A. (2013). Debt, Money and Mephistopheles: How Do We Get Out of This Mess? [pdf file]. Retrieved from: https://www.fca.org.uk/publication/ archive/debt-money-mephistopheles-speech.pdf

Warburton, C. (1945). The monetary theory of deficit spending. The review of economics and statistics, 27(2), 74-84.

Wright, D.M. (1942). The creation of purchasing power: a study in the problem of economic stabilization. Cambridge, Massachusetts, USA: Harvard University Press. 
Sajid Amin Javed, presently working as Research Fellow at the Sustainable Development Policy Institute (SDPI), Islamabad, Pakistan, holds a $\mathrm{PhD}$ in economics with dissertation on modeling the economic costs of macroeconomic and political uncertainty. Prior to moving to SDPI, he has held senior positions in various institutes/organizations including the Pakistan Institute of Development Economics (PIDE), International Islamic University (IIUI), and the National Institute of Population Studies (NIPS). He has been an international consultant with the Asian Development Bank (ADB), Islamic Development Bank (IDB), and United Nations Development Program (UNDP). He has taken assignments with the Department for International Development, Overseas Development Institute, (DFID, ODI) UK, and the Higher Education Commission (HEC) of Pakistan. He is a Member Working Group on Economic Governance, $12^{\text {th }}$ Five Year Plan, Planning and Development Division; Member Working Group on Macroeconomic Framework-Growth, Investment \& Savings; Member Thematic Research Grant Committee, Higher Education Commission of Pakistan (HEC); Member Committee for Establishing Pakistan Academy of Social Sciences (HEC); Member Working Group on Promoting Remittances Inflows through Legal Channels (Ministry of Oversees Pakistani); External Reviewer on $12^{\text {th }}$ Five Year Monetary Policy and Financial Market plans and visiting faculty at the Pakistan Institute of Development Economics, National Institute of Management; Foreign Service Academy, and National Defense.

E-mail: sajidamin78@gmail.com 


\title{
تمويل العجزبلاحدود من أجل الرخاء الاقتصيادي: كيف أخطأوا فهم فكرة تمويل العجز لكينز؟
}

\author{
ساجد أمين جاويد \\ باحث، معهل سياسات التنمية المستدامة، إسبلام آباد، باكستان
}

المستخلص. إن التيار الأخير من التوصيات بشأن إنشاء ائتمانات غير محدودة لتمويل النفقات

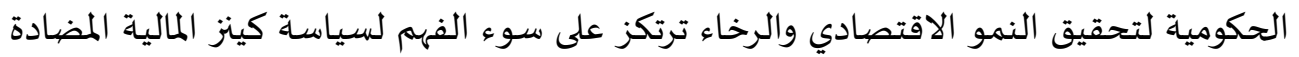
للدورة الاقتصادية. تهدف سياسة كينز في الإنفاق في العجز إلى التحفيز الموجه نحو زيادة

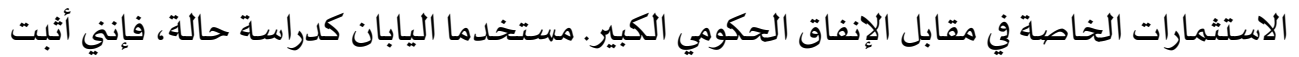

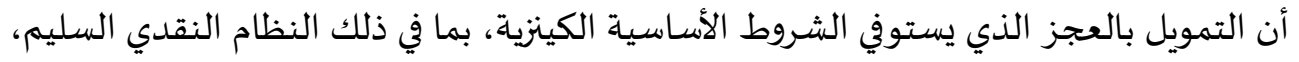
والأسواق المالية المتطورة، ومعدل سعر الفائدة المنخفض/الصفري، قد لا يؤدي إلى زيادة النمو وانخفاض الديون الحكومية كما يتنبأه المؤيدون. وأؤكد على أن التوسع الائتماني غير المحدود

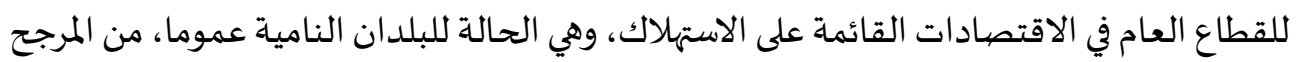
أن يولد التضخم مع ترك إنتاجية الاقتصاد دون تغيير.

الكلمات الدَّالة: كينز، سياسيات كينز، الإنفاق في العجز، خلق الإنتمان، سعر الفائدة، السياسة المالية. تصنيف E12, E51, E62, H63, H81 تصنيف G3, R72, R73, R81 KAUJIE 